\section{Svært god klinisk innføring i fordøyelsessykdommer}

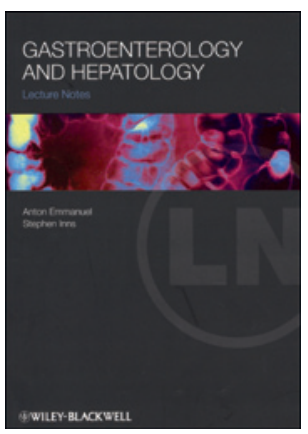

\begin{abstract}
Anton Emmanuel, Stephen Inns
\end{abstract} Gastroenterology and hepatology

Lecture notes. 223 s, tab, ill. Chichester: Wiley-Blackwell, 2011. Pris GBP 24 ISBN 978-1-4051-8321-5

I dette klinisk orienterte verket, i serien Lecture Notes, får vi et raskt og godt overblikk over gastromedisinske og gastrokirurgiske problemstillinger. Hoveddelen er en beskrivelse av organspesifikke diagnoser og funn.

Først gir forfatterne en oversikt over, og klinisk tilnærming til, hva vi møter i vår kliniske hverdag, problemstillinger som magesmerter, leverpatologi, tarmsykdom, ernæringsmessige problemer og infeksjoner. De gir konkrete forslag til hvordan vi kan penetrere anamnesen og systematisk kartlegge og peile oss inn på hvilken lokalisasjon og hvilke differensialdiagnoser det kan dreie seg om. I en nyttig tabell oppsummerer de indikasjoner og begrensninger for bildediagnostikk, endoskopi, kapsel- og isotopundersøkelser og komplikasjoner til noen av disse undersøkelsene. Fysiologiske undersøkelser med pustetester, øsofagusmanometri, transittid og permeabilitetstester er kort beskrevet.

Et eget kapittel om akutte tilstander som gastrointestinale blødninger, akutt øvre og nedre passasjehinder, akutt pankreatitt og leversykdom, er kort, presist og oversiktlig beskrevet med illustrative tabeller. I tillegg er det huskelister over årsaker til symptomer, f.eks. svelgevansker, abdominalsmerter, gastrointestinal blødning og diaré, en punktvis liste over den kliniske undersøkelsen av abdomen inklusive rektaleksplorasjon, vanlige patologiske funn og kasuistikker med spørsmål og svar.

Boken er rikt illustrert i farger med figurer av anatomi, flytdiagrammer og tabeller. Oversiktlige kapitler og avsnitt med tydelige overskrifter gjør det lett å finne frem. Som oppslagsverk over spesifikke sykdommer er den mindre anvendelig - da omfanget ikke tillater å gå i dybden.

Så vel for medisinstudenter, som skal undersøke sin første pasient med gastrointestinal blødning, som assistentlegers introduksjon i gastromedisinen, bør boken være en følgesvenn. Som forberedelse for den som skal undervise helsepersonell, er den en god repetisjon. Den gir et godt grunnlag for å lage undervisningsmateriell. Presentasjonen av kasuistikkene kan være et utgangspunkt for en god diskusjon.

Enhver som har et behov for å oppdatere seg innen gastroenterologi og gastrokirurgi, får her en rask introduksjon, et lett tilgjengelig overblikk og en nyttig oppdatering. Den illustrative og oversiktlige omtalen av utredning og behandling gjør at klinikere raskt vil kunne ta riktige beslutninger og legge fornuftige utredningsog behandlingsstrategier.

\section{Bjørn Moum}

Gastroenterologi

Oslo universitetssykehus, Aker

\section{Villedende tittel}

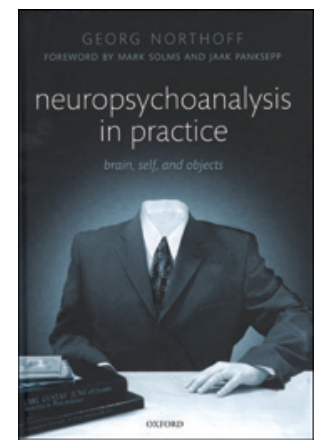

\section{Georg Northoff \\ Neuropsychoanalysis in practice}

Brain, self and objects. 369 s, ill. Oxford: Oxford University Press, 2011. Pris GBP 55 ISBN 978-0-19-959969-1

Dette er en seriøs utgivelse med mye oppdatert informasjon. Forfatteren er en tysk professor som jobber i Canada. Han er psykiater, filosof og først og fremst en produktiv nevroforsker. Men, som vennene hans skriver i forordet, han er ikke psykoanalytiker, og han unnlater helt å skrive om psykoterapi. Forfatteren er også relativt lite interessert i nevrale korrelater til psykoanalytiske begreper og funksjoner. Han fokuserer heller på hvorledes han mener hjernen må struktureres og organiseres nevralt for å muliggjøre og predisponere danningen av psykens subjektive egenskaper, dens evne til å frembringe mening, personlige verdier og normer.

Northoff understreker at mekanismene som ligger under overgangen fra det nevrale til det psykologiske, fra hjerne til psyke, fortsatt er ukjent. Cathexis er Freuds betegnelse for å investere psykisk energi i noe. Northoff kobler dette til nevral energi i «default mode network», den delen av hjernen som viser mye aktivitet i hvile, når hjernen ikke mottar impulser; hjernens iboende aktivitet. Den bruker som kjent en god del av kroppens energi og muliggjør det Northoff kaller «nevromental transformering». Han har en hypotese om at denne iboende aktiviteten påvirker stimulusindusert nevral aktivitet (rest-stimulus interaction). Det gjør det mulig for hjernen å påvirke og forme de ulike innkommende stimuli. Omvendt påvirker stimulusindusert aktivitet hvileaktiviteten (stimulus-rest interaction).

De faktisk innkommende stimuli sammenliknes med det forventede. Dette gir opphav til «forskjellsbasert koding». Slik koding bruker hjernen til å bearbeide all informasjon, være den nevral, introseptiv, eksteroseptiv eller kognitiv.

Forfatteren har nevrale hypoteser om det ubevisste i drømmer, forsvarsmekanismer, projeksjon og id. Selvet deles opp i basalt og innholdsmessig. Det basale, «selvrelaterte prosesser», utgjøres av hvileaktiviteten $\mathrm{i}$ et integrert subkortikalt midtlinjesystem, eller «default mode network». Slike prosesser er affektive og ikke-kognitive. Innholdet i selvet fylles av laterale, kognitive deler av cortex. Men selvet er ikke noe som er gitt. Det blir konstruert i relasjonene til omsorgsgivere og miljø. Her er han på linje med tilknytnings- og objektrelasjonsteori.

Ved depresjon blir det fokusert, ofte ubevisst, på tidlige tap. Det fører til at energi trekkes tilbake fra opprettholdelse av objekter og selvobjekter (i Kohuts betydning) i voksenlivet. Han har detaljerte nevrale hypoteser både for depresjon og psykose. Ved psykose fokuserer han bl.a. på problemer med selvobjektgrense, med påfølgende mulighet for hallusinose eller vrangforestillinger. Det kan dannes onde selvobjekter, som ikke lenger virker selvstabiliserende.

Boken er full av hypoteser som i varierende grad er underbygd. Den er tunglest og inneholder etter min mening lite av interesse for klinikere. Den er for spesielt interesserte, og understreker hvor vanskelig forskning er på dette grenseområdet.

\section{Anders Evang}

Oslo 